\title{
Solving Transnistria: Any Optimists Left?
}

\section{Cristian Urse *}

Since 1992, there has been an ongoing debate regarding the situation in Transnistria, the breakaway republic on the border between Moldova and Ukraine. After the conclusion of the agreement that ended the armed conflict, the Moldovan government in Chişinău and the Transnistrian authorities in Tiraspol made efforts to find a political solution, under the supervision of a negotiation mechanism that included, until the end of 2005, Russia, Ukraine, and the OSCE. Russia's 2003 plan to that end was rejected by the Moldovan leadership. This triggered a set of political and economic punishments from Moscow. The political changes of 2005 have given a new impetus to the negotiations on the resolution of the Transnistrian conflict. The changes in Georgia and Ukraine and the resuscitation of GUAM have significantly influenced the premises for a settlement, while the United States and the European Union have become observers in the negotiations format.

At the end of 2007, however, the prospects of solving the Transnistria issue are no longer that promising. The present negotiating mechanism continues to lose relevance. Meanwhile, developments in Kosovo, relevant for the case of Transnistria, are taking international affairs down a path where the frozen conflicts of the former USSR are losing importance as time goes by.

This article argues that the decisions of the actors involved have negatively affected the negotiating mechanism. During 2005-06, the parties took unilateral steps that they perceived as likely to improve their position in the future. Meanwhile, the heated debate on Kosovo and the tangled political evolution of Ukraine in the last two years have seemed to lead the conflict in Transnistria to a dead-end, at least in the short and medium term.

\section{The Conflict in Transnistria}

Some scholars have tried to explain the war in Transnistria as an ethnic conflict. Without understating this dimension of the conflict, it is necessary to examine the region's ethnic realities more closely. In 1989, Moldovans made up roughly 65 percent of the entire population of Moldova. Ukrainians ranked second, at around 14 percent, and Russians third, with 13 percent. In Transnistria, Moldovans were still a relative majority (40 percent), while Ukrainians formed 28 percent of the population, and Russians 26 percent. ${ }^{1}$ However, the minorities used Russian as a means of communication. Therefore, the claim that the language law of August 1989 provoked concerns among the Russian-speakers is true to a certain extent. This legislative package decided that the state language be Moldovan, and that a return to the Roman alphabet should take place. It also stated that language profi-

* Cristian Urse is a diplomat in the Ministry of Foreign Affairs of Romania. He holds an M.A. in Russian and East European Studies from Georgetown University. Since October 2004 he has been an associate lecturer at the University of Bucharest, Department of Sociology and Social Work. The author bears exclusive responsibility for the opinions and arguments made herein.

1 Charles King, The Moldovans: Romania, Russia, and the Politics of Culture (Stanford, CA: Hoover Institution Press, 2000), 97, 185. 
ciency would be required of all citizens by 1 January 1994 (although it guaranteed the use of Russian and Gagauz at the local level). ${ }^{2}$ Nevertheless, unlike in the Baltic States, the requirement for proficiency in the state language was never enforced in Moldova.

Factors other than ethnicity appear to have made more significant contributions to the breakout of the conflict. In Transnistria, the Moldovan national agenda clashed with the Soviet ideological conceptions and the economic interests of the local leaders. Within the framework of the Soviet development plans, most of the industrial infrastructure of Moldova was built in Transnistria. It was therefore profitable for its leaders to attempt to secede in order to preserve full control of the region's economic assets.

Since the end of World War II, Transnistria has always been seen as a source of reliable cadres for the Moldovan Communist Party. Immediately after 1945, Transnistrian Communists were considered more loyal to the USSR than their colleagues from the recently integrated province of Bessarabia. Therefore, in the first decades after the war, the party leaders in Chişinău usually came from Tiraspol. This situation began to change after a couple of decades. ${ }^{3}$ By 1989, the Moldovan Party leaders were often from Bessarabia, and were the key players in promoting perestroika and the national awakening movement that emerged at that time. Tiraspol was still an important economic center of the republic, but its leaders feared they would lose their positions under the pressure of the reformist movement. Thus, trying to preserve their traditional positions, Transnistrian leaders found themselves fighting perestroika and, later on, the Moldovan national movement.

After the adoption of the language laws in Moldova, groups of workers from the Eastern bank of the Dniester went on strike to express their concern with the would-be requirement of proficiency in the state language. In June 1990 the Supreme Soviet of Moldova adopted a declaration of sovereignty. In September, the reaction of Transnistrians was to proclaim the Dniester Moldovan Autonomous Republic (RMN). The Moldovan Supreme Soviet declared this act null and void, but could not enforce this decision on the ground. While pursuing its own path to independence, Chişinău was losing control of Transnistria.

In the days of the August 1991 coup in Moscow, Mircea Snegur (the first Moldovan president) and the Moldovan leadership sided with Mikhail Gorbachev and condemned the plotters. On the opposite side, the Transnistrian leadership hailed the putsch, stated that the Soviet Union must be saved, and promised troops to the plotters. Once the coup failed, Transnistrians rushed to set up their self-proclaimed state.

In December 1991, the first serious clashes between the paramilitary detachments of the RMN and the Moldovan police broke out in Dubăsari (Transnistria), over control of government buildings. Reportedly, the Transnistrian forces used weapons from the deposits of the Soviet $14^{\text {th }}$ Army. In March 1992, hostilities occurred again in Dubăsari, extending then to other localities. In response, Moldovan president Snegur declared a state of emergency throughout the country.

2 Erika Dailey, Human Rights in Moldova: The Turbulent Dniester (New York: Human Rights Watch, 1993).

3 King, The Moldovans, 135. 
The Soviet $14^{\text {th }}$ Army was a key factor in the conflict. In early 1992, the Moldovan president tried to secure control over this formation and issued a decree that transferred all the former Soviet military troops and equipment to the emerging Moldovan Defense Forces. That decree remained a simple piece of paper, and on 1 April President Yeltsin officially transferred the $14^{\text {th }}$ Army to the Russian Federation command. ${ }^{4}$ In May, the $14^{\text {th }}$ Army launched attacks against Moldovan forces, driving them out of some villages on the left bank of the Dniester. The bloodiest fighting occurred in June, when the $14^{\text {th }}$ Army again intervened (this time officially) in favor of separatists who were losing the city of Tighina (Bender), driving out the Moldovan forces. ${ }^{5}$ On 21 July 1992, a peace accord was signed by presidents Yeltsin and Snegur, providing the establishment of peacekeeping forces comprising Russian, Moldovan, and RMN troops, under the supervision of a Joint Control Commission.

\section{Attempts to Negotiate}

Beginning in April 1992, talks between the representatives of Russia, Ukraine, Romania, and Moldova led to the creation of a quadripartite mechanism for the resolution of the conflict, and a cease-fire agreement mediated by the four parties was signed. A meeting of the presidents of the four states was held in Istanbul in June 1992, establishing the creation of security zones and corridors, while the status of the $14^{\text {th }}$ Army remained to be determined in future Russian-Moldovan consultations. The Russian-Moldovan agreement of July 1992 effectively put an end to the quadripartite mechanism, leaving Romania and Ukraine outside the process of negotiation, as Russia no longer considered it necessary to consult Bucharest (or Kiev). The Moldovan leadership thus inexplicably put its fate in the hands of Moscow, in an obviously disproportionate negotiation.

On 21 October 1994, Moldova and Russia signed an agreement calling for the withdrawal of the Russian troops within three years. The document was criticized by Moldovan experts and former members of the negotiating commission for two reasons: it stipulated the principle of synchronization of the withdrawal with granting autonomous status to Transnistria, and it was ambiguous with respect to the date of its entering into force. ${ }^{6}$ Moldova ratified the agreement immediately and expected that Russia, doing the same, would proceed with withdrawal by 1997. By 1996, however, Moscow had not ratified the agreement, asserting that the status of Transnistria should take precedence over its military commitments. The document thus became obsolete.

Ukraine was later included in a new format of discussions, with Russia's blessing, in an attempt to give negotiations on Transnistria an international face. Thus, in 1997, Chişinău and Tiraspol signed a memorandum intended to normalize their relations, with Russia, Ukraine, and the OSCE as guarantors of the subsequent negotiating process. Three years later, in 2000, President Putin established a state commission presided over by former Foreign Minister Yevgeny Primakov, which was tasked to elaborate a plan for the settle-

4 Mihai Gribincea, The Russian Policy on Military Bases: Georgia and Moldova (Oradea: Editura Cogita, 2001), 157.

5 Dailey, Human Rights in Moldova: The Turbulent Dniester, 16.

6 Gribincea, Russian Policy on Military Bases, 181-92. 
ment of the Transnistrian matter. During the same year, the commission presented a document that advanced the idea of a "common state" of Moldova and Transnistria, within the recognized borders of the Republic of Moldova, based on a special treaty guaranteed by Moscow and Kiev. As the proposal favored Tiraspol, advancing even the idea of Transnistria's right to secede from Moldova under certain circumstances, it was silently set aside by Chişinău, whose interests were seriously jeopardized by such a provision.

The lack of progress after ten years has to be understood not only as the consequence of a lack of involvement on the part of the international community. Moldova made important mistakes, like the one in 1992 that terminated the consultation mechanism that included Romania and Ukraine, or like the conclusion of an unclear agreement in 1994. Meanwhile, the speed of negotiations has also depended on the evolution of relations between the governments in Chişinău and Moscow. Good relations with Russia were not accompanied by substantial progress in the negotiations on Transnistria. Russia, for its part, was content with maintaining the status quo, which allowed her to have full control in Transnistria and an important lever to be used from time to time to pressure Chişinău.

This oscillation of the Moldovan leadership in relation to Russia had two damaging effects. First, it allowed Russia to interpret in its favor the confusing or even sometimes contradictory bilateral documents. Second, it made the international community reluctant to get involved in a dispute that time and again seemed to be regarded as a bilateral issue by both Chişinău and Moscow.

\section{The Kozak Memorandum}

In 2001, after early elections, the Party of Moldovan Communists (PC) came into power, taking advantage of a negative vote that punished the lack of success of the reformist alliance that had formed the previous government. The Communists won the elections on a pro-Russian platform. Among other things, they favored Moldova's membership in the Russia-Belarus Union, a project that did not materialize. However, close relations with Russia and an anti-Western rhetorical stance dominated their political discourse. According to the new provisions of the Moldovan Constitution, the president of the republic was elected by the parliament. With 71 seats (out of 101), the Communists did not have any problem with electing their leader, Vladimir Voronin, as the country's president.

With respect to Transnistria, Voronin and the Party of Moldovan Communists seemed convinced that they would be able to bring it under Chişinău's control. As early as 2001, the discussions with the Transnistrian leadership appeared to be bearing fruit. As a promising result, one of the political prisoners held in Tiraspol, Ilie Ilaşcu, was freed. ${ }^{7}$ The leadership in Chişinău believed that its close relationship with Moscow would ensure a smooth resolution of the conflict, with Voronin emerging as a strong and successful leader

7 As of 1992, four Moldovan citizens who fought on Chişinău's side during the war were held prisoner in Tiraspol, after a Soviet-style "trial." One was released in 2001. In 2004, the European Court of Human Rights condemned Russia for their illegal imprisonment and asked for their immediate release and for compensation to be paid. Russia paid the compensation, but claimed no responsibility for the imprisonment, blaming it all on Tiraspol. The last prisoners were released after serving the full sentence meted out at the "trial," in total disregard of the European Court decision, whose credibility will be questioned ever after this. 
able to reunite the country. Unfortunately for them, those expectations have proven to be mere wishful thinking.

In 2002, representatives of Russia, Ukraine, and the OSCE submitted a draft for an agreement between Chişinău and Tiraspol. The document proposed the federalization of the country, within which territorial entities (Transnistria first) were supposed to retain power over a wide spectrum of issues. President Voronin's stated goal was to hold elections throughout the entire republic (including Transnistria), in hopes of a peaceful and legitimate takeover of the left bank of the Dniester. By mid-2003, however, negotiations had stalled once again.

Faithful to Moldova's relationship with Russia, President Voronin entered into direct negotiations with Moscow, leaving Ukraine and the OSCE aside. The Russian Deputy head of the Presidential Administration, Dmitri Kozak, was tasked by President Putin with reaching a compromise between Chişinău and Tiraspol on constitutional matters. Kozak's shuttle diplomacy was able to produce a document by October 2003, detailing the principles of a federal structure that favored Tiraspol. Thus, Moldova was to become an asymmetric federation, with only one unit clearly defined: Transnistria. The remaining part of the country was referred to in the document as "the federal territory," while Gagauzia was supposed to be represented in the newly established upper house of the parliament, with an option to elevate its status within the future federation. The way the upper house of the parliament was supposed to make decisions on important matters (such as organic laws) gave Transnistria a de facto veto, as a three-fourths majority was required for such decisions. $^{8}$

After the document was apparently agreed to in both Chişinău and Tiraspol, Russia presented it to the OSCE and Ukraine, the other guarantors of the negotiation process. Aware of the underlying Russian-Moldovan negotiations, the OSCE had tried to get involved during 2003, but Russia had constantly refused to give it a role. In accord with its Istanbul commitments, Russia was supposed to withdraw its troops and ammunition from Moldova at the end of 2002, during the Portuguese chairmanship of the organization. A one-year extension granted by the ministerial conference held in Lisbon brought that term to December 2003. Therefore, the situation was of particular importance for the Dutch chairmanship of the organization at the time. Feeling shunted aside, the chairman was more than suspicious with regard to the document that Russia presented in late 2003. Moreover, the United States clearly signaled that it would not favor the agreement. ${ }^{9}$

On the other hand, public opinion within Moldova exerted intense pressure on the country's leadership to block the conclusion of the agreement. The Kozak Memorandum was seen as an inadmissible concession made by the Communist government to Russia and a tether holding Moldova hostage to Russian interests for years to come. The document came at the end of a year during which the opposition had been rallying in the streets for many weeks, protesting against the government's policy on language matters, as 2003 was the year when the Communist government tried to elevate the status of the Russian lan-

8 Steven Roper, "Federalization and Constitution-Making as an Instrument of Conflict Resolution," Demokratizatsya 12:4 (Fall 2004).

9 John Löwenhardt, "The OSCE, Moldova and Russian Diplomacy in 2003," Journal of Communist Studies \& Transition Politics 20:4 (December 2004). 
guage (making it almost the second official language of the country), while questioning the use of Romanian history and language textbooks in schools. The Kozak Memorandum thus became an excellent opportunity for the opposition to stage another round of public demonstrations, making the situation even more difficult for the government. ${ }^{10}$

Last but not least, it appeared that the final form of the document contained a couple of elements that upset President Voronin and his government. ${ }^{11}$ The initial draft of the memorandum contained no reference to the situation of the Russian troops in Transnistria. However, at Tiraspol's request, Russia agreed to offer guarantees that its troops would remain in the region for another twenty years. ${ }^{12}$ At this point, although he had initialed the document, Voronin realized that his main objective - that of bringing Transnistria under his control, and subsequently emerging as a hero to his electorate-would never be achieved. The continued presence of the Russian troops eliminated the prospects for a peaceful change of the political elite in Tiraspol, which was actually obtaining a role in the decision making process in Chişinău. All of Moldova would have become, in effect, a hostage of Tiraspol and Moscow.

In the absence of any clear political gain, without any support from the international community, and with public opinion opposing the document, President Voronin decided not to sign it, and canceled the ceremony that was to be attended by the Russian President Vladimir Putin in Chişinău on 25 November 2003. Russia's reaction was harsh, and marked a clear breakdown of its relationship with Chişinău. On its part, Tiraspol was given the chance to claim that Voronin could not be trusted.

The Kozak Memorandum episode was a bitter failure for Russian diplomacy. Instead of putting pressure on Moldova, the entire construction put Moscow in the position of having to ask for the OSCE's support after months of rejecting any serious dialogue with the Dutch chairmanship on Transnistria. As the December ministerial conference was just days away, Moscow had to face Western criticism for failing to abide by the terms that she had agreed to one year earlier, when the extension for the withdrawal of the Russian troops from Moldova had been granted. The subsequent Russian political attack on Voronin was the logical consequence of the outcome of the negotiations.

\section{Moldova After the Kozak Memorandum}

The events that followed deepened the alienation of the Moldovan leadership from its former Russian friends. The OSCE ministerial conference of 2003 was the first to fail to reach a common position on the matter of Russian troops in Transnistria, with Russia trying to ignore its 1999 Istanbul commitments. ${ }^{13}$ The final declaration of the NATO Summit held in Istanbul in 2004 expressed the Allies' regret with regard to Russia's inability to

$10 R F E / R L, 25$ November 2003.

11 The Moldovan side stated that the final draft of the document presented for signature was not the one previously agreed to, while Russia dismissed such an accusation. "Local conflicts: 'Moscow's hand' Got no Support from Russia," Defence \& Security (7 December 2005.)

12 Löwenhardt, "The OSCE, Moldova and Russian Diplomacy in 2003."

13 The same has happened in 2004, 2005, 2006, and 2007. 
comply with the terms of the withdrawal of its troops from Transnistria. ${ }^{14}$ Most important, a July 2004 decision by the European Court of Human Rights stated that Russia contributed decisively to the establishment of the regime in Transnistria, was responsible for the fate of the political prisoners illegally held in Tiraspol by the separatists, and was to pay damages and undertake the necessary steps for their release. ${ }^{15}$ Finally, Moldova itself was under close scrutiny from the Council of Europe for its record in the field of human rights and democratization, which determined some positive changes in those directions. ${ }^{16}$

Because of this particular international political context, as well as the severe deterioration of his relations with Moscow, President Voronin chose to execute an interesting political twist. With no hope of peace with Moscow, he and his party took a pro-European stance in the wake of the general elections of March 2005. The change of government in Romania gave him the opportunity to improve relations with Bucharest, which had previously deteriorated. The outcome of the Ukrainian Orange Revolution also contributed to the viability of this option. The Communist Party won the elections comfortably, gaining the population's approval not only for its pro-European platform, but also for its firmer approach towards Moscow.

The $2+3$ negotiations on Transnistria, which began taking place on a monthly basis as of April 2004, kept Moldova in an uncomfortable position. ${ }^{17}$ As many analysts argued, ${ }^{18}$ there was usually a four-against-one format of debate, with Ukraine and the OSCE mission in Chişinău invariably siding with Moscow and Tiraspol. Constantly isolated in the debates, it was difficult for Chişinău to convince the international community of the righteousness of its position. This began to change in early 2005, when Kiev also chose a proEuropean direction that rendered the government more likely to pay attention to the Western approach towards Transnistria.

The Ukrainian Orange Revolution was a significant factor for Moldova's approach to the Transnistrian matter. First, it changed the balance within the negotiation mechanism. Seeking a closer relation with the EU and NATO, Ukraine began offering nuanced alterations of its position with regard to the conflict, no longer agreeing with all Russian proposals. As an example, under the aegis of the EU, Ukraine concluded a border agreement with

14 NATO Istanbul Summit Communiqué, available at http://www.nato.int/docu/pr/2004/p04096e.htm.

15 The case of Ilascu and others vs. Republic of Moldova and the Russian Federation (available at www.coe.int). In the words of the European Court of Human Rights, "the authorities of the Russian Federation contributed both militarily and politically to the creation of a separatist regime in the region of Transdniestria, which is part of the territory of the Republic of Moldova," and "even after the ceasefire agreement of 21 July 1992 the Russian Federation continued to provide military, political and economic support to the separatist regime [...], thus enabling it to survive by strengthening itself and by acquiring a certain amount of autonomy vis-à-vis Moldova."

16 Since its foreign policy change, Moldova is considered to be playing a more active role in taking into account the Council of Europe's recommendations; an overall improvement of its human rights record has been seen as a consequence.

17 These negotiations were between Chişinău and Tiraspol, with Russia, Ukraine, and the OSCE as mediators.

18 Vladimir Socor, "Unedifying Debut to 5+2 Negotiations on Moldova," Eurasia Daily Monitor (1 November 2005). 
Moldova in late 2005, aimed at eliminating the illegal traffic that went through the Transnistrian sector of the Ukrainian-Moldovan border.

Second, and more importantly, changes in Kiev caused Moldova to reevaluate its entire foreign policy. As the events in Ukraine came one year after the Georgian Revolution, the March 2005 Moldovan elections were seen by many in the West as an opportunity for "the next colored revolution" in the former Soviet area. Although it is not clear what popular support such a revolution would have had, Moldovan opposition parties borrowed political symbols and slogans from their neighbors; thus, during the electoral campaign, the Christian Democratic Popular Party adopted the color orange and used a poster in which its leader and the Ukrainian President Yushchenko appeared together. Improving relations with Moscow was no longer an option for Voronin and the Communist Party. Even worse, certain Russian political circles signaled that they would support a centrist coalition in the Moldovan elections. Thus, the government in Chişinău picked the only viable option for its electoral platform, that of the European integration project. The Communist Party retained an absolute majority of parliament seats (54 out of 101) and reached an agreement with an opposition party that secured another term for President Voronin.

The most important political outcome of the March 2005 elections was the solid proEuropean stance of all political parties represented in the parliament. In 2001, the Communists opposed the pro-European discourse of the opposition, and even debated the potential membership of Moldova in the Russia-Belarus State Union. By 2005, the project of European integration was embraced by all significant parties that entered the electoral race.

With regard to Transnistria, this offered the premises for a more active policy. On 10 June 2005, following a settlement plan presented earlier by the President of Ukraine, Viktor Yushchenko, the new Moldovan Parliament adopted with a large majority three documents regarding the future status of Transnistria. The documents spoke about the necessity of decriminalizing, demilitarizing, and democratizing the Transnistrian area of Moldova, while at the same time granting it a large degree of autonomy. The parliament's move did not have any immediate practical consequences, as Transnistrian leaders did not renounce their own agenda with regard to the presence of Russian troops in the area. However, it had a strong symbolic impact, showing that Moldova was no longer in a defensive position on the Transnistrian matter on the international stage. On the contrary, Tiraspol (along with Moscow) was supposed to react to Moldova's proposals. As expected, Transnistria repeatedly stated its opposition to what it perceived to be an "asymmetric federation," 19 claiming equal status with Chişinău within a future political arrangement, and also maintaining a different view with regard to the long-term presence of Russian troops.

By the end of 2005, Moldova signaled that she considered the negotiating format obsolete and, failing its reformation, would renounce it. ${ }^{20}$ As a result, Tiraspol and Moscow agreed to have the U.S. and EU as observers in the negotiating format. Rather than improving the debates, the new equilibrium strengthened Moldova's capacity to disagree

\footnotetext{
19 “Transdniestria Against Asymmetric Federation with Moldova," Itar-Tass Weekly News (19 July 2005).

20 Chişinău and Tiraspol plus Russia, Ukraine, and the OSCE.
} 
with Moscow and Tiraspol and further undermined the prospects for reaching a solution within this framework.

Another result of Ukraine's change of orientation was the reactivation of GUAM. ${ }^{21}$ As Moldova, Georgia, and Azerbaijan all had to deal with Russian-supported territorial separatism, GUAM became an appropriate framework to address these concerns, increasing international pressure on Russia. On 23 May 2006, the GUAM Summit in Kiev decided to institutionalize the organization, renamed The GUAM Organization for Democracy and Economic Development, and established its secretariat in the capital of Ukraine. The Summit Declaration condemned the occupation of a country's territory by military force, stating that "territorial annexations and the creation of enclaves can never become legal," a clear reference to the frozen conflicts in Moldova, Georgia, and Azerbaijan. In their individual declarations, the presidents of Moldova and Azerbaijan were even more explicit in pointing to the secessionist movements on their territories, calling for a better coordination of GUAM members in international organizations on topics related to those conflicts. ${ }^{22}$

In November 2005, Moldova and Ukraine concluded an agreement regarding the Transnistrian side of their border. The agreement, backed by Brussels, provided for a strict joint control of the Ukrainian side of the border, with the participation of an EU Border Assistance Mission. The mission consists of sixty-nine experts seconded by EU countries and around fifty local support staff; its two-year mandate has just been extended up to 2009. It has its headquarters in Odessa, and another six field offices along the MoldovanUkrainian border. ${ }^{23}$ The mission is aimed at capacity building for border management, through improving customs controls and creating an effective monitoring mechanism on the Transnistrian segment of the Moldova-Ukraine border, and is supposed to curb the illicit traffic that allowed the survival of the separatist regime in Tiraspol. ${ }^{24}$ As part of its commitment, Moldova facilitated the registration of Transnistrian firms with the authorities in Chişinău, renouncing its rights to tax these businesses. Thus, Moldova began exerting symbolic control over these firms, making them legitimate and allowing them to trade abroad.

Since April 2005, Moldova has had to face another problem. The Russian authorities banned imports of meat products, fruits, and vegetables, a decision seen by many analysts as pressure exerted by Moscow in order to punish Chişinău for its conduct in foreign affairs. This decision was extended in 2006 to include Moldovan wine, ${ }^{25}$ which, together with the other agricultural products, was traditionally available on the Russian market. Far from generating compliance, this measure sharpened Chişinău's resolve. President Vo-

21 This regional cooperative organization derives its name from its four original members: Georgia, Ukraine, Azerbaijan, and Moldova. Interfax, 23 May 2006.

23 "Background information on EU Border Assistance Mission to Moldova and Ukraine," available at www.consilium.europa.eu/uedocs/cmsUpload/051129Ukraine_back_separate.pdf.

24 Vladimir Socor, "Moscow Against International Legal Order in Transnistria," Eurasia Daily Monitor (9 March 2006).

25 A similar measure targeted the export of Georgian wine to the Russian market. 
ronin stated that Russian economic sanctions against his country were "the price for independence, sovereignty, and territorial integrity" that the people would continue to pay. ${ }^{26}$

Georgia and Moldova signaled in 2006 that they might question Russia's accession to WTO if the ban on agricultural exports continues. Russia's ban is seen as a unilateral sanction against two WTO members, an act that is not in line with the organization's rules. While it is not clear how much weight Georgia and Moldova's opposition might carry against Russia's bid for WTO membership, this is one more political problem for Moscow.

Commentators have pointed out another step that would make the situation more difficult for Moscow. In October 2005, the Georgian Parliament required the government to assess the overall activity of the Russian peacekeeping troops in South Ossetia and Abkhazia. In July 2006, the parliament adopted a decision to evacuate the Russian peacekeepers from the two separatist regions, based on the conclusion that their influence was doing more harm than good. The presence of the Russian peacekeepers in Transnistria is based on the Russian-Moldovan agreement that ended the armed conflict in July 1992. ${ }^{27}$ While the resolutions adopted by the Moldovan Parliament in June and July 2005 asked for the withdrawal of the Russian troops (in line with the Istanbul commitments), the government in Chişinău has been reluctant to denounce the 1992 agreement, in order to avoid a unilateral step that might have been criticized by the international community. However, this option remains viable, especially after the decision of the Georgian Parliament. The termination of the agreement would make illegal the presence of Russian troops on Moldovan territory, forcing Russia to take into consideration the idea of an international peacekeeping force (eventually under a UN mandate). Talks have been already held in May 2006, in Brussels, in a 3+2 framework (Russia, Ukraine, OSCE as mediators and the U.S. and EU as observers), on the idea of transforming the present peacekeeping operation in Moldova into an international one. ${ }^{28}$ The simple fact that Russia agreed to discuss the matter speaks for itself.

Moldova's active foreign policy during 2005-06 marked a substantial difference from the previous period. Chişinău has acted independently of the constraints of the negotiating format. First, the Moldovan Parliament adopted a package of resolutions and laws that addressed the problem of the status of Transnistria. Second, Moldova threatened to withdraw from negotiations, short of a reform of its format composition (driving the invitation of EU and U.S. as observers). Third, Moldova took advantage of the new political context in Ukraine, increasing its bilateral cooperation with Kiev. Moldova was thus able to secure the implementation of the border agreement with Ukraine, denounced as an "economic blockade" by Moscow and Tiraspol, and made use of GUAM on the international stage. In sum, Moldova has proven it was prepared to act independently from the existing negotiating mechanism.

26 Rusia la zi, 23 June 2006.

27 Vladimir Socor, "Moldova Can Follow Georgia's Example on Russian 'Peacekeeping' Troops," Eurasia Daily Monitor (15 May 2006).

28 Vladimir Socor, "Proposal on the Table to Transform Russian 'Peacekeeping' in Moldova," Eurasia Daily Monitor (30 May 2006). 


\section{Moldovan Leadership in 2007}

However, 2007 has brought unexpected changes in the attitude of the Moldovan President. Returning to the mode of oscillating policy, Voronin found reason to launch public attacks on Bucharest, while attempting reconciliation with Moscow. Romania was blamed for being too assertive in regard to the Romanian identity of Moldovans. The Moldovan President accused Bucharest of financing various publications and "even political forces" within Moldova, in an attempt to "Romanianize" his country. ${ }^{29}$ Bucharest was also blamed for granting Romanian citizenship to Moldovan citizens, allegedly to the same end. ${ }^{30}$ To mark his divorce with Romania, President Voronin has even questioned the legitimacy of his country's national symbols - the flag, the coat of arms, and the national anthemadopted, according to him, "through a backdoor maneuver" in $1990 .{ }^{31}$

This attitude was accompanied by a sustained effort to improve relations with Russia. Rumors spread about a bilateral deal between Moldova and Russia with regard to Transnistria in the summer of 2007. President Voronin publicly admitted in July 2007 that talks with Russia were underway, arguing that Russia was a traditional partner that Moldova should not alienate. Part of the deal regarded lifting the ban on Moldovan exports to Russia, which started to materialize as a token of good will throughout 2007. In her turn, Moldova pledged not to oppose Russia's accession to WTO membership.

These reactions of President Voronin came as no surprise to anyone who has followed the evolution of Moldovan domestic politics. In June 2007, the Party of Communists suffered a serious setback in the local elections. The Communists again lost the mayoralty in Chişinău, while anti-communist coalitions started to form in most Moldovan cities' local assemblies. Voronin's anti-Romanian rhetoric and a friendly approach to Russia were easily read as an attempt to reach out to the traditional electorate of the Party of Communists, with a view toward the general elections of 2009.

In the same vein, irritated by criticism of his back-door talks with Vladimir Putin on Transnistria, President Voronin expressed his disappointment with the West's lack of support, as he perceived it, in a speech delivered to the assembled Western ambassadors on 28 June 2007. He stated that talks with Russia were mostly economic, and that he was hoping Moscow would soon lift barriers to imports of Moldovan products, signaling that not enough progress had been made in the economic sphere in Moldovan-West relations. With regard to Transnistria, while acknowledging talks with Russia, President Voronin said that any proposal would have to eventually become public and be discussed in the parliament.

Finally, by the end of 2007, on the same anti-Romanian stance, President Voronin accused Bucharest of undermining the settlement of the Transnistrian conflict. He stated that

29 Evenimetul Zilei, interview with President Voronin, 12 November 2007.

30 According to the Romanian legislation, former Romanian citizens and their descendants can claim Romanian citizenship under certain, favorable conditions. It is especially the case of former citizens from the Republic of Moldova, who lost their citizenship as a consequence of the Soviet occupation in 1940.

31 The Moldovan flag is the same as the Romanian one, having in addition the national coat of arms on it (which is also similar to that of Romania). 
every time a solution for Transnistria seems close, Romanian politicians start taking steps in the opposite direction. ${ }^{32}$ This statement was accompanied by another groundless allegation: "Bucharest does not see the Republic of Moldova as an independent and sovereign country." 33 Curiously, this statement was made at the time when Russia was opening polling stations in Transnistria for the parliamentary elections held on 2 December 2007, a far more serious challenge to Moldova's integrity and sovereignty. This event has been, however, treated in a quiet and more calculated manner by Chişinău. ${ }^{34}$

Increasing tensions with Bucharest might pay off in Moldovan domestic politics, but it is far from bringing about any good in the international arena. These problems are perceived as going hand-in-hand with the bilateral negotiations with Russia, negotiations that excluded any Western involvement, a mistake that President Voronin also committed at the time of the Kozak Memorandum. The difference is that, in 2007, the West is more committed than back in 2003 to solving the conflict. In 2005, the U.S. and EU became part of the 5+2 negotiating mechanism, as observers, while the EU agreed to send the Border Assistance Mission to the Moldovan-Ukrainian border. As proof of this interest, Western diplomats have insistently asked for the would-be Moldovan-Russian confidential agreement (which resulted in a nervous reaction from President Voronin in June 2007), and they did so in order to avoid losing face as observers to the negotiations who were unaware of a secret accord. Therefore, a private Moldovan-Russian deal would be badly resented by the U.S. and EU, and would seriously damage Chişinău's relations with the West.

\section{Status Quo: Russia’s Profound Wish}

After the failure of the Kozak Memorandum, Russia tried to discredit Moldova in the eyes of the international community. Russian officials declared that the leaders in Chişinău could not be trusted, as they changed their mind at the last moment with respect to the agreement with Russia. This line of argument continued throughout 2004, when an OSCE proposal redrafted the main ideas of the Russian plan for the settlement of the conflict. However, this came too soon after the experience of the Kozak Memorandum, in a time of mounting political tension between Chişinău and Moscow.

As the March 2005 elections did not bring a significant political change in Moldova, Russia proceeded with economic sanctions against Chişinău. Although it cited internal regulations (regarding levels of pesticides, heavy metals, etc.) that the Moldovan (and Georgian) products did not comply with, Russia had little success convincing international opinion that the measures were anything other than economic retaliation against the political attitude of the two countries. On the other side, Moldovan officials stated that no laboratory evidence was presented by Russia in support of its decision, while the country continued to export wine to other markets that were equally interested in consumer safety. ${ }^{35}$

Mediafax, 27 October 2007.

Ibid.

34 "Moldova Objects to Russian Polling Stations in Dniester Region," ITAR-TASS Daily (30 November 2007).

35 Economist Intelligence Unit, Country Report, Moldova, May 2006, available at www.eiu.com. 
The 2007 rapprochement between Russia and Moldova has brought some changes in Russia's policy with regard to Moldovan agricultural exports. Russia has agreed, in the first place, to allow some wine exports, mainly from Russian-owned wineries in Moldova. By the end of 2007, it signaled that most of the bilateral problems with regard to wine export had been solved, expecting some support for its WTO bid in exchange.

Also in 2007, Moscow chose to challenge the West in the security arena. The Russian authorities kept saying that they had fulfilled all legal commitments undertaken at the 1999 OSCE Istanbul Summit, and repeatedly demanded that NATO states ratify the Adapted CFE Treaty. Short of such ratification, Russia has threatened to suspend the implementation of this treaty. The Extraordinary Conference of the State-Parties to the CFE, held in Vienna from 11-15 June 2007, failed to bring about an agreement between Russia and NATO. Russia withdrew from the treaty, a decision that became effective as of 30 November 2007, which Moscow tried to present to public opinion as a "suspension," although the treaty does not include such a clause. The entering into force of the decision on the last day of the OSCE Ministerial Conference in Madrid has shown that Russia is ready to further discredit the OSCE in order to achieve its individual goals.

With Kosovo being expected to declare independence from Serbia, the situation in the Balkans has attracted most of the attention of the international community, casting Transnistria and the other frozen conflicts in its shadow. ${ }^{36}$ Moscow has tried to make a parallel between the frozen conflicts in Moldova and Georgia on the one hand and the status of Kosovo on the other. As international negotiations on Kosovo's final status began in early 2006, Russian officials (including President Putin) stated that Kosovo should be regarded as a precedent for settling the post-Soviet frozen conflicts. Tiraspol's announcement that it would hold a referendum on independence in September 2006 was encouraged by Moscow. Thus, Konstantin Kosachev, president of the Russian Duma's Committee for Foreign Relations, declared that a transparent referendum should be taken into consideration by the international community as a legitimate expression of the will of the people of Transnistria. ${ }^{37}$ However, Russia has no reason for rushing to formally recognize the independence of the separatist province, and there are several reasons for this.

First, it is by now clear that Russia will not agree to a negotiated solution on Kosovo along the lines spelled out by the Ahtisaari Plan. No form of conditional or supervised independence of Kosovo is acceptable for Russia, who prefers to strengthen its ties with Serbia and block a UN Security Council decision on the fate of the province. Russia is preparing the ground for extracting the maximum political benefits from this situation, while claiming to defend a legalistic point of view. Once the U.S. and some EU countries recognize Kosovo's independence, Russia will have one more reason to disregard its 1999 Istanbul commitments. It will claim that the West has undermined international law by not respecting the territorial integrity of Serbia. While pointing to the misconduct of the U.S. and drawing a parallel with Transnistria and the other frozen conflicts, Russia will most probably increase the support granted to the separatist regimes in the former USSR and assure their security. Recognition of independence would be a risky step, and it is not clear

${ }_{37}$ Kosovo declared independence from Serbia on 17 February 2008.

37 ZIUA, 18 July 2006, available at www.ziua.ro. 
who would follow a would-be (but unlikely) unilateral recognition of Transnistria's independence by Moscow. On the contrary, maintaining the status quo will allow Russia to claim a pacifist and legalistic role at the same time.

Second, Russia would be worse off if it recognized Transnistria's independence. On the one hand, Moscow would face some international criticism from the West, although she could invoke the Kosovo "precedent." OSCE's Chairman in Office in 2005, Belgian Foreign Minister Karel de Gucht, has strongly criticized the idea of a referendum in Transnistria, calling upon Tiraspol to cancel the initiative and to rejoin the negotiations mechanism, while making clear that the OSCE has no intention to observe or support the organization of a referendum that would question Moldova's territorial integrity. ${ }^{38}$ The Kosovo parallel can work only to a limited extent; beyond that, the different histories of the conflicts, the long-term presence of international monitoring in Kosovo, and the internationally supervised negotiations that were lacking in the case of the post-Soviet frozen conflicts will be valid arguments against such a comparison. On the other hand, in the long run, an independent Transnistria (sandwiched between Ukraine and Moldova) might become less responsive to Moscow's wishes. Keeping the elite of Tiraspol completely dependent on Moscow seems the best strategy Russia has in its arsenal.

Third, such an extreme stance would definitively alienate Moldova from Russia for years to come. At present, Moldovan politicians stress from time to time the need to maintain good relations with Russia. Some do so just for the sake of rhetoric, while others seek some kind of electoral payoff. However, if Russia recognizes Transnistria's independence, no politician in Chişinău will ever again speak favorably of Moscow.

Russia has been successful so far in maintaining the status quo. The agreement of 1992 allowed the consolidation of the Transnistrian leadership, and the one in 1994 tried to link the settlement of the conflict with solving the status of Transnistria. Every time she proposed a solution, Russia intended to legalize a potential right of secession of Transnistria from Moldova, or at least to ensure a veto right for Tiraspol on the most important decisions made in Moldova. Short of such a decision, Russia undermined any other Moldovan efforts to solve the problem.

Moscow expected a change in Moldovan politics after the March 2005 elections. As this did not occur, Russia played the card of economic retaliation against Moldova, while hoping for a change in Ukraine with the March 2006 elections. Thus, Russia paid less attention to the $2+3$ negotiations on Transnistria, hoping for a positive (for her) political change in either Moldova or Ukraine. This discredited the negotiating mechanism, which has been unable to achieve any significant progress.

\section{Ukraine's Approach to the Transnistrian Conflict}

In June 2006, the Ukrainian Foreign Minister Boris Tarasyuk expressed his support for Romania's participation in the existing negotiating format on Transnistria. ${ }^{39}$ Openly opposed by Russia and previously rejected also by Ukraine, this turn-about has surprised

38 ZIUA, 22 July 2006, available at www.ziua.ro.

39 ZIUA, 28 June 2006. 
many. Nevertheless, at the time Tarasyuk might have reached the conclusion that Ukraine should not oppose Russia on the topic of Transnistria alone, preferring to share the burden.

During President Kuchma's regime, Ukraine was a quiet ally of Russia as far as Transnistria was concerned. Odessa was arguably the key transit point for the traffic of goods to and from Tiraspol. Ukraine's attitude changed after the Orange Revolution in December 2004, as it moved closer to the West. Kiev presented its own plan for the settlement of the conflict in April 2005 (known as "The Yushchenko Plan"), ${ }^{40}$ while advocating for the inclusion of the U.S. and EU in the negotiation mechanism (which Moldova had proposed earlier). Ukraine went even further, concluding the border agreement with Moldova that had been strongly condemned by both Moscow and Tiraspol. Thus, the government in Kiev came under severe criticism from Russia, not a comfortable position within the context of its difficult bilateral talks with Moscow (including critical negotiations on the supply of natural gas).

Throughout 2005 and in the first half of 2006, Ukraine maintained its position with respect to Transnistria, further upsetting Tiraspol and Moscow. While visiting Chişinău in June 2006, the Ukrainian foreign minister stated that restoring Moldova's territorial integrity and sovereignty is one of his country's foreign policy main tasks. ${ }^{41}$ Tarasyuk went on to accuse Moscow and Tiraspol of blocking the negotiation mechanism, using the "false excuse" of an "economic blockade" against Transnistria. In return, some pickets in Transnistria named Tarasyuk an agent of the United States and "inspirer of Ukraine's antiTransnistrian actions." ${ }^{, 2}$ Kiev's position was no longer as vocal after the Yanukovich government was sworn in, and rumors about illegal trafficking to and from Transnistria have once again begun to spread. Nevertheless, the EU Border Assistance Mission remains in place, and its mandate has been extended for another two years, up to November 2009.

At the OSCE Istanbul Summit in 1999, Russia committed to withdraw its troops and ammunition from Moldova by 2002. Ukraine's role was expected to increase with respect to the long-term settlement of the conflict. Thus, by 1999, the Transnistrian leadership was openly criticizing Russia's decreasing involvement in Transnistria, meanwhile advocating for Kiev's broader participation in the settlement of the conflict. ${ }^{43}$ Ukraine was seen at the time as the natural successor of Russia regarding the provision of security guarantees for Transnistria, as Moscow appeared ready (and willing) to give up, in the long run, its former empire.

However, Russia's ambitions grew again after Vladimir Putin came into power in 2000. As Russia reaffirmed its readiness to continue assisting (and protecting) the elites of the breakaway regions of Moldova and Georgia, Ukraine's profile did not increase as expected. Furthermore, as the current Ukrainian leadership has stated its goal of joining NATO, the Russian troops in Transnistria could be, in the near future, an effective lever for Russia in its relationship with Ukraine. Public protests by the Russian-speaking popu-

40 Eugen Tomiuc, "Chişinău, Tiraspol Welcome Ukrainian Plan, but Settlement Remains Far Off," RFE/RL, 18 May 2005; available at www.rferl.org/featuresarticle/2005/5/76C623AB-1188-4357BAD2-C5CCAFE766BB.html.

43 “Moscow's Tiraspol Problems," Defence \& Security (3 February 1999). 
lation of Crimea in 2006 led to the cancellation of a joint Ukraine-U.S. military exercise, a fact that raised concerns in Kiev. A strong (or even independent) Transnistria that would allow the continuous presence of Russian troops in the region could only serve to increase those security concerns. A declaration by Russia's minister Sergey Ivanov showed that Russia continues to cast about for various arguments for maintaining its troops in Transnistria. Ivanov has accused the global community of applying a double standard in the assessment of the foreign military presences of Russia and the United States, arguing that, while 2,500 U.S. troops were to be deployed in Bulgaria as a result of a U.S.-Bulgarian agreement, Russia was being unjustly criticized for its 1,500 peacekeepers in Transnistria. ${ }^{44}$

Thus, there is no surprise that Ukraine wants an effective settlement of the Transnistrian issue, including the withdrawal of Russian troops. ${ }^{45}$ Facing Moscow's criticism for the border agreement concluded with Chişinău, Ukraine wanted to share the responsibility of opposing Moscow in the future with other countries from the region. Romania's participation in the negotiation format would be, in this view, beneficial for Ukraine.

With a recent history dominated by government instability, Ukraine remains a key factor to the settlement of the Transnistrian conflict. However, this lack of stability prevents her from also being an actor in this game. The newly sworn-in Ukrainian government will have to deal again with issues related to Russian gas deliveries and other bilateral challenges that will render Transnistria a marginal topic of discussion for Kiev.

\section{The OSCE, the EU, and the U.S.}

In 1993, an OSCE mission was established in Chişinău. As with other similar missions, it was supposed to deliver updated reports about the evolution of the security environment in the country. Because the OSCE was directly associated with the negotiating mechanism in 1997, the mission in Chişinău was assigned the responsibility to represent the organization for that purpose. The mission has come under constant criticism from Moldovan civil society in recent years, as it usually supported Moscow's initiatives, which were perceived in Chişinău as contrary to Moldova's interests. One idea on the table since 2005 has been Moldova's proposal to internationalize the peacekeeping force in Transnistria, but Chişinău has thus far been careful to avoid offering the OSCE a major role in such an effort, hoping that the EU will be more involved.

The EU has been a reluctant actor in the frozen conflicts in the post-Soviet realm. The Union seems to be unwilling to directly confront Russia on issues related to the former Soviet space, although this is by now the organization's immediate neighborhood. One obvious explanation is Europe's dependence on Russia's energy resources. Another is the difficulty of articulating a coherent, far-reaching European foreign policy. Nevertheless, the EU took some steps that addressed the matter. Broadly speaking, in May 2004 the Union elaborated the European Neighborhood Policy, a plan designed to enhance cooperation with countries in her immediate vicinity, based on bilaterally agreed action plans.

44 Itar-Tass Weekly News (31 May 2006).

45 Vladimir Socor, “Orange Two Government Can Meet the Transnistria Challenge,” Eurasia Daily Monitor (29 June 2006). 
For Moldova, a progress report is due in 2008, three years after the approval of the action plan. More specifically, the EU decided to politically and materially support the initiative of monitoring the Moldovan-Ukrainian border in order to cut off the illicit traffic that sustains the regime in Tiraspol, meanwhile issuing a visa ban against seventeen leaders of the separatist movement. At the end of 2005, the EU became an observer to the negotiation process on Transnistria.

The EU was, however, less vocal than the U.S., the other observer of the negotiations as of 2005. The U.S. continues to maintain its unequivocal stance with regard to the CFE Adapted Treaty: no NATO country should ratify it as long as Russia does not fulfill its Istanbul commitments regarding the withdrawal of its troops from Moldova and Georgia. As a result, the CFE Treaty Review Conference failed to reach an agreement over a final document, with Russia on one hand and NATO members on the other holding opposite positions. ${ }^{46}$ The presence of Western observers (and especially of the U.S.) in the negotiating mechanism helped Moldova escape the constant pressure of Russia. At present, the U.S. is Moldova's main guarantee that it will not be left alone in the future talks on Transnistria. In his official statement at the Ljubljana Ministerial Conference of the OSCE in December 2005, U.S. Under Secretary of State Nicholas Burns made clear that, in line with the CFE Treaty principles, Moldova and Georgia have the right "to decide whether to allow stationing of foreign forces on their territory," and that the two countries "have made their choice." Therefore, Russian troops should leave their territories. ${ }^{47}$

However, Russia's withdrawal from the CFE Treaty leaves the West without an important lever of pressure. A new U.S. proposal regarding Moldova appears to show more flexibility towards Russia, in an effort to break the stalemate in the negotiations on Transnistria. ${ }^{48}$ It follows the idea of transforming the peacekeeping operation in Moldova into an international one, while giving the mission an important civilian dimension. The proposal would give the EU a major role, while maintaining an important Russian presence. However, if implemented, this solution would legalize the presence of the Russian troops. On the other hand, Russia's influence could thus be limited, as the EU would never become Moscow's prisoner in a future negotiating format. Another effect will be the eventual termination of the present negotiating format itself (and its replacement with a substantially different one), as an EU peacekeeping mission would never act under a mandate established by the current negotiating mechanism. ${ }^{49}$

46 "No Final Document Adopted at the CFE Treaty Review Conference," Itar-Tass Weekly News (3 June 2006).

47 R. Nicholas Burns, Under Secretary of State for Political Affairs, "Remarks to the Thirteenth Ministerial Council of the Organization for Security and Cooperation in Europe," Ljubljana, Slovenia, 5 December 2005; available at www.state.gov/p/us/rm/2005/57647.htm.

48 Vladimir Socor, "U.S. Proposal Tolerates Russian Military Presence in Moldova," Eurasia Daily Monitor (30 December 2007).

49 The EU will never risk the termination of its mission following a decision by Tiraspol or Moscow. 


\section{Conclusion}

The developments of the past several years offer little hope for a solution in Transnistria. Yet further prolongation of the status quo and a diminution in the importance of the current negotiating mechanism seem to be the most likely outcomes of the present state of affairs. The unilaterally declared independence of Kosovo will also favor these outcomes.

The enlargement of the negotiating mechanism on Transnistria in September 2005 raised hopes for a final settlement of the conflict. After months of interruption, the resumption of the negotiations, along with the decision to invite the U.S. and EU to join as observers, was seen as the beginning of a fruitful phase of discussions. President Voronin welcomed the presence of EU and U.S. representatives at the negotiations, hoping that this would help the parties reach an agreed solution. ${ }^{50}$ In fact, this moment marked a substantial change in the political environment with regard to Transnistria. Far from bringing a solution closer, the enlargement of the negotiations format brought the old framework of dealing with Transnistria closer to its end.

During 2005-06, Moldova took important steps outside the negotiating mechanism. In June and July, important legislation was passed by the parliament, including a document laying out a set of general principles regarding the autonomous status of Transnistria within the Republic of Moldova. In November 2005, Chişinău concluded a border agreement with Kiev, which came into force four months later. The agreement, aimed at eliminating illicit traffic over the Transnistrian sector of the Moldovan-Ukrainian border, was supported by the EU, but strongly condemned by Russia and Tiraspol.

However, Moldova's behavior in 2007 was confusing enough to make its Western partners reluctant. Back-channel bargaining with Russia raised serious concerns, and the way President Voronin responded to them in June was even more confusing. The EU extended the mandate of the Border Assistance Mission for another two years, but this mission is already becoming part of the picture of the new status quo, and it is hard to imagine an enhancement of the EU's participation.

The U.S. continued to state that the 1999 Istanbul commitments still matter, but seems ready to show some flexibility with regard to the way that these commitments will materialize, with the CFE Treaty now seriously endangered. ${ }^{51}$ After all, the Moldovan leadership might have lost in 2007 a good part of what it gained in 2006 in terms of Western support.

Blaming Romania for all of Moldova's problems might help President Voronin in national elections, but will hardly help him challenge the status quo over Transnistria. Romania is not necessarily important for maintaining the present level of Western support, but it is key to bringing about any positive change. The EU will maintain its Border Assistance Mission in place, regardless of Moldovan-Romanian relations, but it will hardly agree to any new course of action without the consent of Bucharest. Meanwhile, uncertain of the state of Moldovan-Russian relations, both the U.S. and the EU will be cautious not to get too involved in negotiations, given the risk of being presented with an undesired (and unexpected) back-channel agreement between Chişinău and Moscow.

50 Itar-Tass Weekly News (4 October 2005).

51 They were mentioned by the U.S. Under Secretary of State at the OSCE Ministerial Conference held in Madrid, as at the previous ministerial conferences. 
The Kosovo issue seems to carry important consequences for the fate of Moldova. It drove Transnistria and the other frozen conflicts off the radar as it captured the lion's share of international attention. The U.S. and some European nations are now concerned with how to present Kosovo's independence as acceptable to the international community. In such a context, nobody is willing to further challenge Russia on other matters. Given these tensions, maintaining the status quo in Transnistria might be perfectly acceptable.

The recognition of Kosovo by the U.S. and others will give Russia the opportunity she was looking for in order to maintain the present situation in Transnistria. Without formally recognizing the separatist regimes in the former USSR, Russia will increase the level of support provided to them, and will assure their de facto existence: it will welcome Transnistrian (and other separatist) leaders in Moscow, it will boost economic ties with Tiraspol, and it will draw parallels between Transnistria and Kosovo in public speeches. Short of a UN Security Council Resolution, Kosovo's recognition will give Russia an excuse for keeping its troops in Transnistria indefinitely.

Ukraine realizes it needs a solution in Transnistria along the lines of Moldova's interests, emphasizing reintegration of the country and withdrawal of the Russian troops. A continuation of the status quo or recognition of Transnistria will increase Kiev's difficulties with respect to dealing with Russia, as accommodating Moscow is often at odds with Western interests in Moldova. However, given its current political instability, Ukraine has given up - at least in the short run - any prospects of becoming an actor in the negotiations on Transnistria. She will have to constantly bargain with Russia over energy resources for years to come, and only strong Western encouragement could persuade Kiev to speak up seriously for the withdrawal of the Russian troops from Moldova.

Finally, President Voronin himself seems to have given up his hopes with regard to Transnistria. He and the Moldovan leadership have reluctantly condemned the opening of Russian polling stations in Transnistria for the 2 December parliamentary elections without the approval of Chişinău, a serious issue that officially calls into question Moldova's integrity and sovereignty. Instead, they were vocal in accusing Romania of somehow undermining the settlement of the conflict, a piece of rhetoric clearly aimed at the domestic audience, with little international consequence (other than upsetting Bucharest). Transnistria is thus becoming more of a domestic campaign issue, well-suited to securing some public support, but the Moldovan leaders seem to have lost faith in actually solving the problem. 


\section{THE QUARTERLY JOURNAL}

\section{Bibliography}

Dailey, Erika. Human Rights in Moldova: The Turbulent Dniester. New York: Human Rights Watch, 1993.

Gribincea, Mihai. The Russian Policy on Military Bases: Georgia and Moldova. Oradea: Editura Cogita, 2001.

King, Charles. The Moldovans: Romania, Russia, and the Politics of Culture . Stanford, CA: Hoover Institution Press, 2000.

Löwenhardt, John. "The OSCE, Moldova and Russian Diplomacy in 2003." Journal of Communist Studies \& Transition Politics 20, no. 4 (2004).

Moscow Against International Legal Order in Transnistria. Eurasia Daily Monitor (2006).

R. Burns, Nicholas. Remarks to the Thirteenth Ministerial Council of the Organization for Security and Cooperation in Europe In Under Secretary of State for Political Affairs. Ljubljana, Slovenia, 2005.

Roper, Steven. "Federalization and Constitution-Making as an Instrument of Conflict Resolution." Demokratizatsya 12, no. 4 (2004).

Socor, Vladimir. "Moldova Can Follow Georgia's Example on Russian 'Peacekeeping' Troops." Eurasia Daily Monitor (2006).

Socor, Vladimir. "Orange Two Government Can Meet the Transnistria Challenge."Eurasia Daily Monitor (2006).

Socor, Vladimir. "Unedifying Debut to 5+2 Negotiations on Moldova." Eurasia Daily Monitor (2004). 